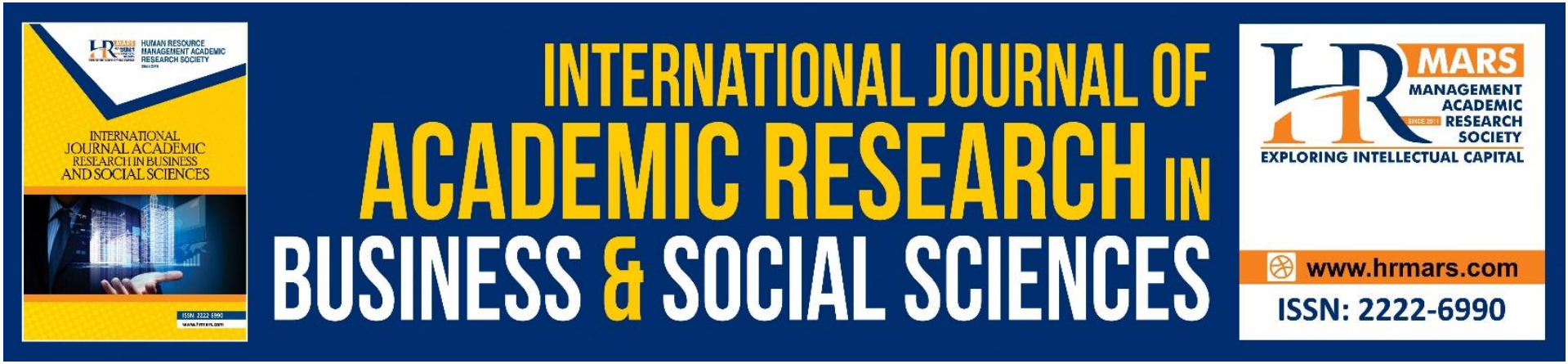

\title{
A Study on Ghanima and Fai' as Warfare Property of Early Islam: The First Twenty Three Years
}

\author{
Mohd Farid Mohd Sharif, Azimah Abdullah
}

To Link this Article: http://dx.doi.org/10.6007/IJARBSS/v11-i10/10621 DOI:10.6007/IJARBSS/v11-i10/10621

Received: 06 August 2021, Revised: 10 September 2021, Accepted: 30 September 2021

Published Online: 12 October 2021

In-Text Citation: (Sharif \& Abdullah, 2021)

To Cite this Article: Sharif, M. F. M., \& Abdullah, A. (2021). A Study on Ghanima and Fai' as Warfare Property of Early Islam: The First Twenty Three Years. International Journal of Academic Research in Business and Social Sciences, 11(10), $692-704$.

\section{Copyright: @ 2021 The Author(s)}

Published by Human Resource Management Academic Research Society (www.hrmars.com)

This article is published under the Creative Commons Attribution (CC BY 4.0) license. Anyone may reproduce, distribute, translate and create derivative works of this article (for both commercial and non-commercial purposes), subject to full attribution to the original publication and authors. The full terms of this license may be seen at: http://creativecommons.org/licences/by/4.0/legalcode

Vol. 11, No. 10, 2021, Pg. $692-704$

Full Terms \& Conditions of access and use can be found at http://hrmars.com/index.php/pages/detail/publication-ethics 


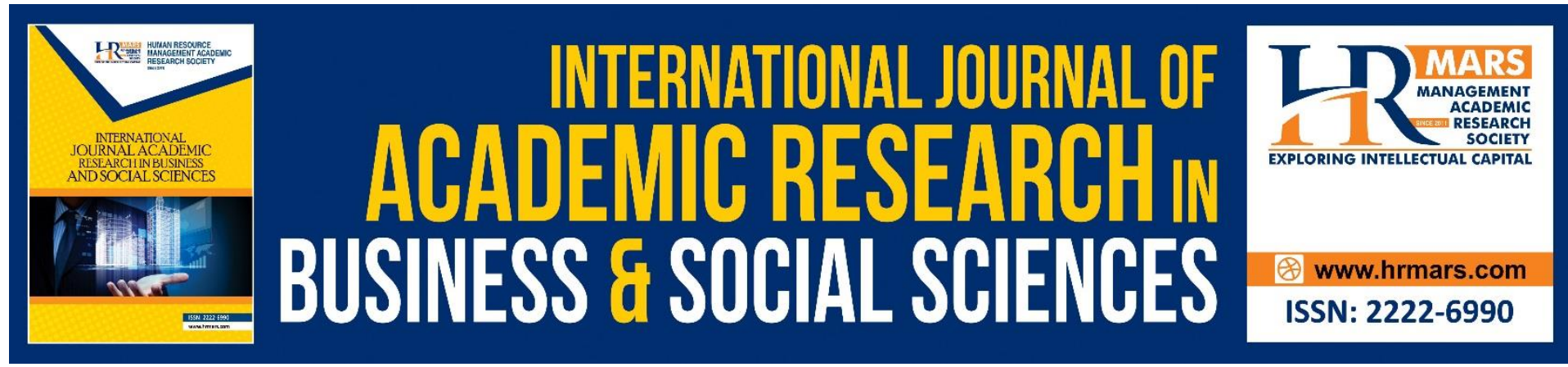

\title{
A Study on Ghanima and Fai' as Warfare Property of Early Islam: The First Twenty Three Years
}

\author{
${ }^{1}$ Mohd Farid Mohd Sharif, ${ }^{2}$ Azimah Abdullah \\ ${ }^{1}$ School of Humanities, Universiti Sains Malaysia, ${ }^{2}$ Institut Pendidikan Guru, Kampus Sultan \\ Abdul Halim, Kedah
}

\begin{abstract}
s
This article sheds light on these issues from several angles, explaining the content and development of the notion ghanima and fai', its usage in Islamic law, and giving a short overview of the development and sources of the warfare property in Islamic history. Analysis done towards the texts of the Quran and hadiths show that Muslims who were involved in wars are given a special rights to own a predetermined rate of portion from ghanima and fai'. This privilege, however should not be given a narrow interpretation, for example assuming Islam only cares about wealth or that Muslims are greedy as they are willing to struggle to join the battle just to get that privilege. The philosophy behind it is to give motivation in the battles of jihad al-qital, plays an important role to help the economy of Muslims who sacrificed a lot materially, and to avoid arguments among Muslims because the distribution has become final. This philosophy indirectly denies the negative assumption that Muslims who were involved in wars are materialistic. The article concludes that the matter of ghanima and fai' shows that Islam has set methods and guidelines to managing the financial gains of a country, as well as, ownership rights of individual wealth.
\end{abstract}

Keywords: Ghanima, Fai', Jihad al-Qital, Warfare Property, Islamic Law

\section{Introduction}

Initially, warfare properties could not be taken and owned by the people of the olden days. The prohibition was later revoked after the descent of the verses of the Quran in the Chapter al-Anfal. According to Latif (2014), the question about warfare property specifically refers to the dialogue that happened between members of Badr (Muslims who were involved in the Battle of Badr that happened on 17 Ramadan, $2 \mathrm{AH}$ at a place called Badr near Medina) with the Prophet Muhammad (Lings, 1983; Guillaume, 1998). The dialogue happened right after the Battle of Badr ended and this incident was recorded in the Quran and became the beginning of Chapter al-Anfal (Latif, 2014). The essence of the dialogue of the members of Badr was about questions and answers regarding the distribution of warfare properties obtained through that battle.

According to the above verse of the Quran, explanation has been given that spoils of war belong to Allah and the Prophet Muhammad. Therefore, only Allah and the Prophet Muhammad deserve to determine the way they are being distributed. There is a hadith from 
the Prophet Muhammad that mentions about the prohibition of owning spoils of war to then human. The hadith was narrated by Abu Huraira (d. $681 \mathrm{CE}$ ): "the spoils of war were not made lawful for any people before us, this is because Allah saw our weakness and humility and made them lawful for us" (Muslim, 2010). In this hadith, it has been demonstrated that the Prophet Muhammad maintained about the status of spoils of war being not lawful to the then human and was later made lawful to his umma (community).

The results from previous studies have reported that the discussion about the concept of spoils of war also has a close relationship with the financial management affairs of a country (Omer, 2014; Mitrasing, 2014). Therefore, many classical scholars and modern researchers usually place the discussion about the concept of spoils of war under the umbrella of the topic regarding politics and manoeuvers. One of the most significant classical discussions in this area is done by Abu al-Hasan b. Muhammad al-Mawardi (d. $1058 \mathrm{CE}$ ). He placed his opinions about spoils of war in Kitab al-Ahkam al-Sultaniyya. As the title suggests, the content of the book discusses a lot about affairs pertaining the management of the political system of an Islamic nation. In the same vein, in the book al-Siyasa al-Shar'iyya fi Islah al-Ra'i wa al-Ra'iyya, Ahmad b. 'Abd al-Halim or Ibn Taymiyya (d. 1328 CE) inserted his argument about spoils of war under the topic 'al-Amwal al-Sultaniyya' (national income property). For the past fifty years, in modern literature, the scope of discussion about spoils of war is also still placed under the political umbrella and become an important area in Islamic political thought. Central to the entire discussions of spoils of war in Islamic law is the concept of Islamic political thought or al-Siyasa al-Shar'iyya. A number of authors have already shown an interest and contributed to this area. For example, researchers like Khadduri (1955), Islahi (1988), Muhammad Firdaus (1999), Kelsay (2003) and Bouzenita (2007) usually place their respective arguments about spoils of war around the scope regarding Islamic political thoughts. This development shows that for over the half century the issue of spoils of war in Islam has received considerable critical attention.

\section{Spoils of War at the time of Prophet Muhammad}

In the early days of Islam, wars, battles or jihad qital, as maintained by Sharif (2011), had become of resolving conflicts that happened among humans. Scholars like Sharif (2011) and Badara \& Nagatab (2017) have argued that boundaries or geographical boarders between each territories were divided according to classical fiqh moulds: Dar al-Islam is defined as the realm of Islam, territory under the authority and sovereignty of Islamic law, its protection and security being in Muslim hands; Dar al-Harb represents its antipode and usually characterised by the lack of Islamic order and security; and Dar al-'Ahd with the contract partners among the population, be they musta'minun (the one who seeks security) or ahl al-zimma (nonMuslims residing in Dar al-Islam or Dar al-'Ahd under the protection of Islamic law) (Sharif, 2006). Overall, there seems to be some evidence to indicate that the division of countries according to the above moulds has shaped military based activities. Therefore, if the umma wanted to adjust to the military scenario, they had to get involved with wars or jihad qital. The concept of jihad qital, eventhough allowed by Islam was based on the defensive attitude with the main objective of protecting the survival of Islam. Therefore, a considerable amount of literature has been published by many historians and biographers of the Prophet Muhammad regarding wars participated by the Prophet Muhammad and Muslims of that time. Even though some of the reports are descriptive, they have mentioned the amount of number or the value of spoils of war obtained by Muslims through each war they participated 
in. To better understand the spoils of war at the time of the Prophet Muhammad, I argue that it is relevant for the information about the value of spoils of war to be revealed here in this article. The writer uses data that was collected by Siddiqi in his research about the income of spoils of war participated by Muslims during the Prophet Muhammad's time. Siddiqi has analysed as many as 38 battles and expeditions that happened between $2 \mathrm{AH}$ to $10 \mathrm{AH}$, a span of eight years. During that time, the total of spoils of war obtained was estimated at $6,157,016$ Dirham. From the table below, we can see that the highest total of spoils of war income was through the Battle of Hunayn which was as much as 3,200,000 Dirham, followed by the Battle of Banu Qurayza which totalled at 720,000 Dirham (Hamidullah, 1973). Meanwhile, the smallest amount was 616 Dirham through the Battle of Uhud.

Table 1: Estimated Value of Spoils of War

\begin{tabular}{|c|c|c|c|}
\hline No & Year & Ekspedition/Battle & (Dirham) \\
\hline 1 & $2 / 624$ & Nakhla & 20,000 \\
\hline 2 & " & Badr al-Kubra & 160,000 \\
\hline 3 & " & Banu Qaynuqa' & 250,000 \\
\hline 4 & " & al-Sawiq & 2,000 \\
\hline 5 & $3 / 624$ & al-Kudr & 20,000 \\
\hline 6 & " & al-Qurada & 100,000 \\
\hline 7 & " & Uhud & 616 \\
\hline 8 & $4 / 625$ & al-Qatan & 52,400 \\
\hline 9 & " & al-Nadir & 300,000 \\
\hline 10 & $5 / 626$ & Duma & 10,000 \\
\hline 11 & " & Muraysi' & 200,000 \\
\hline 12 & " & al-Khandaq & 2,000 \\
\hline 13 & " & Banu Qurayza & 720,000 \\
\hline 14 & $6 / 627$ & al-Qurata' & \\
\hline 15 & " & al-Ghamr & \\
\hline 16 & " & Du al-Qassa & \\
\hline 17 & " & al-Jamum & 70,000 \\
\hline 18 & " & al-Ṭaraf & \\
\hline 19 & " & Fadak & \\
\hline 20 & " & Banu Fazara & \\
\hline 21 & $7 / 628$ & Khaybar & \\
\hline 22 & " & Fadak & \\
\hline 23 & " & Tayma' & 650,000 \\
\hline 24 & " & Wada al-Qura & \\
\hline 25 & $"$ & Najd & \\
\hline 26 & $"$ & Fadak & \\
\hline 27 & $"$ & al-Mayfa'a & 200,000 \\
\hline 28 & " & al-Jihab & \\
\hline 29 & $8 / 629$ & al-Kadid & \\
\hline 30 & & al-Siy & \\
\hline 31 & " & Mu'ta & 50,000 \\
\hline 32 & " & al-Khaḍira & \\
\hline
\end{tabular}


INTERNATIONAL JOURNAL OF ACADEMIC RESEARCH IN BUSINESS AND SOCIAL SCIENCES Vol. 11, No. 10, 2021, E-ISSN: 2222-6990 @ 2021 HRMARS

\begin{tabular}{|c|c|c|c|}
\hline 33 & " & Fatḥ Makka & \\
\hline 34 & " & Hunayn & $3,200,000$ \\
\hline 35 & $9 / 830$ & Bisha & \\
\hline 36 & " & al-Fusl & 150,000 \\
\hline 37 & " & Duma & \\
\hline 38 & $10 / 631$ & al-Yaman & \\
\hline & & Total : & $6,157,016$ \\
\hline
\end{tabular}

Source: Siddiqi (1989)

\section{Ghanima and Fai' as Warfare Property}

To date there has been an agreement about the terms that have been introduced by scholars in the discussion about spoils of war. The terms are ghanima dan fai'. The term ghanima is used in literature that is specific to properties obtained by the Islamic army through looting after a battle had ended. In other words, ghanima is properties taken from the enemy's army through the method of battling and has specific way of distribution (Adam, 1347; al-Qasim, 1989; Khadduri, 1955). Meanwhile, as reported by Khadduri (1955), fai' is loots that are obtained not through battles and is not distributed like the ones obtained from ghanima.

The term of ghanima obtained from the Qur'an is mentioned on verses 41 and 69 in Chapter al-Anfal: "and know that anything you obtain of war booty..."; "so consume what you have taken of war booty (as being) lawful and good, and fear Allah. Indeed, Allah is Forgiving and Merciful". In his useful voluminous works, al-Rahibi (1973) found that these two verses were revealed to give the explanation of ghanima, as soon as the Prophet Muhammad and his army won the Battle of Badr. However, al-Rahibi (1973) makes no attempt to fully define the significance of ghanima to Muslims. From the aforementioned verses in the Quran, a possible explanation is that ghanima are properties obtained from the enemy's army through battles, and it is almost certain that ghanima are properties which are lawful. On that basis, the permission and rights had been given to Muslims who fought in that battle to take their respective earnings. Apart from the Qur'an, the term ghanima is also mentioned in a few hadiths of the Prophet Muhammad, for example the following hadith narrated by Abu Umamah: "verily, Allah has honoured me over the other Prophets, or he said: 'My nation over the nations, and He has made ghanima lawful for us"' (al-Bukhari, 2003). In another hadith narrated by Mu'adh b. Jabal: "We went on an expedition of Khaybar along with the Messenger of Allah and we got ghanima there. The Messenger of Allah divided them among us and placed the rest of them in the ghanima" (al-Bukhari, 2003).

In both of the above hadiths, it can also be concluded that ghanima is a form of property obtained through war. It is worth mentioning again here, apart from that ghanima is lawful, those properties also become the properties of Muslims who are served as murtaziqah (professional soldiers) (Sharif, 2011). Generally much of the classical literatures on loots divides ghanima into two types of property, which are movable property and non-movable property. Included in the first type, namely movable property, as demonstrated by Adam (1347) and al-Mawardi (2002) is individual or a person made prisoner of war either as prisoner of asra (prisoner of war who is an army of the enemy) or prisoner of sabi (women, children and old people who are not armies). Even so, Khadduri (1955) found that not all loots are called ghanima. As mentioned before, the second type of loot is called fai'. Property of fai' is obtained not through the method of war but with the way of peaceful eviction of the enemy 
as mentioned in the Quran on verse 6 of Chapter al-Hasyr (Khadduri, 1955; al-Jammal, 1980). The word ' $a f a$ ' $a$ ' in this verse is used to mean 'gift', it is then followed by the word 'minhum' which means 'from them'. According to al-Rahibi (1973), the accurate meaning from the verse is 'gift from the property left by those evicted.' Therefore, out of this meaning was the word fai' later introduced and used by scholars to refer to loots obtained through the way of eviction.

Another issue relating to ghanima and fai' and is relevant to be mentioned here is that there are a few researchers who have done analyses to identify Allah's rational through the above verses of the Quran giving permission of rights to ghanima and fai' to Muslims. For example, Hamidullah (1973) and Ishak (2000) claim that there is a big possibility that the permission was given because of the poor state of being of the Muslims at that time as a result of long suffering that they endured while in Mecca. Among those participated in the battle were not rich and wealthy. Therefore, when they obtained a victory out of a battle, the situation was not only significant to the survival of Islam but also to the increase of moral of the Muslims. As a reward and appreciation towards their effort and sacrifice to uplift Islam, Muslims were given the rights towards ghanima and fai'. Meanwhile, Khadduri (1955) is in the opinion that rights towards ghanima and fai' can be given to Muslims, even though the property was initially owned by non-Muslims because it is a form of punishment for non-Muslims who chose to fight against Muslims after they were given the offer to embrace Islam or did not want to obey the law of Islam. Khadduri's opinion is agreed by Siddiqi (1989) that the permission was given because most of them were motivated by religion and politics. He added that the ownership towards loots was seldom made the main factor Muslims participated in a battle.

It is interesting to note that Khadduri and Siddiqi's opinion is mostly influenced by the discussion of classical fiqh. For example, the one pointed out by Ibn Taymiyya (1991) that property of ghanima and fai' became the property of Muslims because the initial purpose the property existed was to be used by humans to fulfil their basic obligation which is to worship Allah. As Ibn Taymiyya (1991) argued this is in line with the reality of humankind which is to enslave themselves to Allah. Meanwhile, non-Muslims who also own the same property do not use them to worship Allah, they even do not believe in the truth of Islam's messages. Therefore, Khadduri's opinion is in agreement with Ibn Taymiyya's view which showed that ghanima and fai' it is more relevant for Muslims, who want to use the property to worship Allah, to own the property, compared to non-Muslims. To better understand the mechanism of this property, Ibn Taymiyya (1991) reported that Muslims, however, are strongly prohibited from seizing properties of non-Muslims as they please. In contrary, it has to be done through specific methods that are acknowledged by Islamic law like through the jihad qital or jihad in battlefield.

In an analysis of loots, Siddiqi (1989) detailed four more factors why Muslims were given the rights to own loots. Firstly, the property acted as emolument of subsistence, especially to Muslims who were involved in the country's administration and served as murtaziqah. The example is the case that happened to Abu Bakr (rightly guided caliph; d. 634 CE) after being appointed caliph. He was given emolument amounted to 3,000 dirham. In another report, Muhammad b Sa'd (or Ibnu Sa'd; d. 845 CE) (1957) mentioned 6,000 dirham. Even though the reports only mentioned that the emolument was taken from the Bayt al-Mal's (House of 
Treasury) savings and did not mentioned specifically that the source was spoils of war, Siddiqi (1989) is in the opinion that one of the functions of Bayt al-Mal at that time was also to keep spoils of war. As the sources used only mentioned it in general, it is fair to say that the rate of Bayt al-Mal's property used to pay for emolument was also taken from loots. Secondly, the property was used to bear the cost during wars. As informed, every war needed not a small amount of expenditure to prepare for humans, weapons, transportation, clothes, food and so on. According to Siddiqi (1989), although the sources used did not mention in detail the amount of cost involved, the rough estimation of the war expenditure can be obtained by making a comparison with the report by Ibn Sa'd (1957) about the expenditure used by the Quraysh troops in Mecca. According to the report, expenditure used by the Quraysh troops to prepare for strong troops of 3,000 people in the Battle of Uhud was 50,000 dinar (Ibn Sa'd, 1957). In this case, Siddiqi (1989) is in the opinion that if the expenditure of the Quraysh troops in Uhud is used as the standard estimation, therefore it can be estimated that the total expenditure of war participated by Muslims during the Prophet Muhammad's life can reach to almost 15 million dinar or 180 million dirham. Although the estimation is seemed much higher than the actual value of income of loots (see table 1 ) nevertheless the number clearly proves that the expenditure used by Muslims in wars was not small. The third factor is to bear the cost to care for the welfare of war prisoners. In this case, Siddiqi (1989) points the example of services given by Muslims to the prisoners of the Battle of Badr. As reported by al-Tabari (d. 923 CE) (1961), all welfare aspects of the prisoners of the Battle of Badr were well taken care of. Besides, there were a few Muslim armies who made effort to provide food and places to stay for them. The same situation happened to the prisoners of Battle of Hunayn. They were given food and clothes. A large portion of the help was not obtained for free and the expenditure was bore through the income of spoils of war.

It is hard to disagree with Siddiqi (1989) that spoils of war more or less played an important role in the maintenance of the economy of Muslims, but the value was not that big and significant to increase their economy. In order to sketch a more picture of this argument, it is necessary to present a brief description of social condition of the Muslims community in the Prophet Muhammad's time. Muslims during that time relied more on other main activities like trade, agriculture, handicraft and labour. In the conclusion made by Siddiqi $(1989,113)$ he commented as follows:

"...we come to the profile of the Muslim economy of the Arabian Peninsula during the first decade of the Islamic state. Essentially there were four kinds of economic activities; trade and commerce; agriculture; handicraft and manufacture, and manual labour. But it may be said here that the first two vocations, trade and agriculture, served as the backbone of the Muslim economy of the period; the role of the last two was not, however, very insignificant."

Nevertheless, after a careful examination made on Azad (1980), Zahir (1980) and Brockelmann (1952), it may well be true to say that there seemed to be a consensus among historians and biographers of the Prophet Muhammad, that war expeditions participated by Muslims during the Prophet Muhammad more or less affected the strength and improvement of their sociopolitics and socioeconomic whether they are Muslims or non-Muslims. The above discussion should be enough to help us formulate most of the general principles and 
ideas of ghanima and fai' in the modern discourse and in particular, the study done by Siddiqi. The explanation of the methods of distributing ghanima and fai' will be discussed in the next paragraph.

\section{Distribution of Ghanima and Fai'}

Before going into details of the method of distributing spoils of war, it needs to be mentioned again that the rights towards spoils of war was generally given by Islamic law to the Muslims. Nevertheless, on the technical side, the property can only be owned and taken by the Muslims involved in the war and could not be given to the Muslims who were not involved in the war. Khadduri (1955) holds the view that the spoils the of war also cannot be given to the Muslims who arrive late in a war or who arrive right after the war has ended or while the army are gathering properties obtained through the war. The above rule was mentioned by al-Sarakhsi (1906) and Ibn Rushd (1984) through a statement made by "Umar b. al-Khattab (Rightly Guided Caliph; d. 644 AD): "spoils of war belong to those who witnessed the war."

Malik b. Anas, however, has excluded a few types of people from receiving their shares of the spoils of war, which are the ones in the categories of slave, worker and crew member. Even though they were present to witness the war, their presence in the war happened indirectly because they were carrying certain tasks for the leader or their respective master, therefore these people are not included in the categories of serviceman and army (Khalilieh, 1998). A broader perspective has been adopted by Ibn Rushd (1984) who included the observer team as those who are eligible to claim their shares of the spoils of war. He presented his view based on the above hadith narrated by 'Umar b. al-Khattab because the observer team was present and also witnessed the war. But Ibn Rushd (1984) placed two additional rules: firstly, the observer team must clearly show attitude and support siding the Muslim army; and secondly, the rate that is given to them must differ and be less than the rate received by regular servicemen. The method of distribution based on the task categories like the one formulated by Ibn Rushd above was also agreed by al-Kindi (1984). Khalilieh (1998) mentioned that the distribution rate of ghanima as mentioned by al-Kindi is determined based on the rank and seniority of each army officer. Therefore, it is apparent from this argument that any army officer categorised as senior, professional and more experienced are qualified to obtain a larger portion of distribution compared to a regular officer. However, the difference of rate of distribution of spoils of war according to the above categories, was not agreed by lbn Taymiyya. He was in the opinion that all parties involved and witnessed the war were obligated to be given the same rate distribution (Ibn Taymiyya, 1991).

Apart from the discussion on the types of people or the recipients of ghanima, it is also worth mentioning here that many scholars heightened the debate about the duration in which the spoils of war must be distributed. Recent evidence suggests that the spoils of war can be distributed while the servicemen are still at Dar al-Harb or after they have returned to Dar alIslam (Khadduri, 1955). Al-Syaibani (1997), however, did not allow the distribution of spoils of war being done at the area of Dar al-Harb except after receiving the agreement of imam and when a situation happens in which the distribution needs to be done immediately based on the consideration of imam. According to Khadduri (1955), the method is more similar to the method used by the Prophet Muhammad during the Battle of Muraysi', Battle of Khaybar and Battle of Hunayn. 
From the aspect of the rate of distribution of ghanima, the fraction formula that is being used is the fifth method. The rate that is being fixed by scholars is four fifth of the ghanima portion is for the servicemen and the remaining one fifth is distributed to six asnaf (beneficiaries of ghanima): God, the Prophet Muhammad, the Prophet's family (descendants of Hashim and 'Abd al-Muttalib), orphans, poor people and travellers out of resources (Khadduri, 1955). The rate of distribution was mentioned in the Quran, in chapter al-Anfal, verse 41. Yusuf (1970) was in the opinion that one fifth of the ghanima portion as mentioned in the verse above must be distributed to three asnaf: firstly, to Prophet Muhammad or to the rulers after his demise; secondly to the family of Prophet Muhammad; and thirdly to orphans, poor people and travellers. In other words, the last three types are placed under one așnaf and are only given one portion to be shared. However, Ibn Rushd (1988) and Ibn Taymiyya (1991) were in the opinion that the one fifth must be distributed fairly amongst Muslims regardless whether they are poor or rich.

In the case of agricultural land of Sawad in Iraq and Southern Mesopotamia that was obtained by 'Umar through war, records show that a dialogue happened amongst the companions about the distribution method of the properties (Khadduri, 1955). Many of the companions were in the opinion that every new territory that was successfully concurred and all properties within the territory were accordance with ghanima. However, 'Umar personally did not agree that if the properties were to be distributed according to the one fifth formula like it was done to other ghanima. He even was in the opinion that technically, the properties obtained were not categorised under ghanima. The properties were better off frozen to benefit the future generations and must be managed to obtain better interests and returns for the departments of military and defence. As the properties were not categorised as ghanima, then 'Umar suggested that the property owners pay property tax (kharaj) to the country. Through that method, then the country would not lose source of income that can be obtained from those properties. It was in the norm that when the benefit of a suggested policy was not immediately, it would face objections because of the attitudes of some people who wanted to defend existing norm. Even though in the beginning, 'Umar's view or ijtihad in the matter was not well taken by some other companions, however they were finally satisfied and accepted it as an innovation in the process of making laws regarding the distribution of warfare properties (Khadduri, 1955). In addition, the ability and high cognitive skill, like the ones owned by 'Umar, to predict the country's long-term direction was considered an advantage and was not usually owned by every person.

The novelty in 'Umar's above view has set a precedent to all contemporary scholars to revaluate the distribution of ghanima and fai' as to fit the current reality in the context of a modern country. It is widely known that in today's world, military matters require a huge amount of expense and the country needs to prepare a high cost to launch its administration. Besides, its management also has a long-term planning impact towards the survival of the country and the Muslims. The analysis reported here appear to support the view that ghanima initially belonged to the Muslims that were involved in wars, therefore, if it is deemed more appropriate and beneficial, the rights can also be given to the country. In fact, an army is definitely seen as an important safety device of a country and its management is the responsibility of the country. Therefore, according to al-Qaradawi, the country deserves to take the whole portions of ghanima to bear the military costs like to prepare trainings, infrastructure, weaponry, wages, pensions, compensations and insurances (2009). This 
situation is different compared to the situation during the Prophet Muhammad's time. At that time, the administration system was easy and there was not a specific organisation or department that managed the army welfare systematically like there is today. In fact, a large number of army officers bore the costs to join war campaigns themselves. When society becomes more advanced, the technology used gets more sophisticated. So do the military equipment and defence system. All of the advances will not be obtained and later maintained if a country is not able or fails to prepare sufficient costs. Therefore, the decision-making process that took into account the factors of current socio-economic and sociopolitics, is seen to fulfil the objective of law (maqasid) determination.

It is also worth mentioning here, this decision-making process can be understood by looking at the following fiqh method: "actions taken by a ruler towards his people must be based on maslaha (the common good) (al-Zarqa, 1989)." This fiqh method is considered important to the country and becomes the guideline every time the country wants to determine any policy towards its people. In other words, maslasa that is meant covers all welfare aspects of the people like safety assurances, occupations, religious matters, education and freedom. That is the rationale or justification as to why the method of ghanima distribution during the classical times, which used the one fifth formula is deemed inappropriate and impractical to be realised nowadays. It seems that 'Umar's ijtihad tendency in the case was not only based on analyses of divine texts, but was built based on the purpose behind the Islamic law itself.

\section{Conclusion}

This study has shown that Islam has set methods and guidelines to managing the financial gains of a country, ownership rights of individual wealth and all their efforts in using and managing their personal wealth. The next major finding was also shown that the reality of wealth ownership is returned to God. Taken together, these results suggest that humans themselves belong to God and the rights awarded to humans is the caliphate rights that contains the responsibility to bring peace to earth and to manage the matters of human life. The results of this study support the idea that the wealth concept in Islam, like the one agreed by many scholars, obtained necessary recognition and can act as a medium to manage the system that continues the survival of humans. The Quran also explains that humans are awarded with wealth, in which the situation only symbolises the rights to take advantage of God's wealth and to channel it to those who are deserving through the method recommended by Islam. These findings may help us to understand the domination of wealth is more of a responsibility to manage and to take advantage of it for one's self, the community, country and religion as being trusted upon.

On the matter of warfare properties, the most obvious finding to emerge from this analysis is that Muslims are given a special rights to claim a portion and respective ownership. The ownership towards ghanima and fai' like the one explained in the hadith that it was not lawful towards humans of the olden days but was later made lawful to the Muslims. Besides, the Quran also mentions ghanima as a property that is good (tayyiban). Based on that principle, it was also shown that the special permission was therefore given to the Muslims who were involved in wars to own a predetermined rate of a portion. Another thing that needs to be said is that the privilege that was given to the Muslims to own loots should not be given a narrow and negative interpretation. Like assuming Islam only cares about wealth or that the Muslims are greedy as they are willing to struggle to join the army just to get that privilege. 
The determination of the rate of loots portion by the Quran and hadith has its own philosophy which is to give motivation in the battles of jihad qital which becomes an important method of resolving conflicts among humans, besides it becomes an important tool to help the economy of the Muslims who sacrificed a lot materially. The next philosophy is to avoid arguments among the Muslims because the distribution has become final. In addition, in the discipline of figh, many scholars have presented a discussion about the concept and distribution of spoils of war or warfare properties. However, from all the studies reviewed so far, it can thus be suggested that the matter of ghanima and fai' has gained attention from scholars; and all additional rules that they presented were able to show that the method of the distribution of ghanima and fai' are systematic. What is more, I found that one possible implication of this study is that they implicitly denies the negative assumption that the Muslims were materialistic.

Turning to the evidence on the incident involving the discussion between 'Umar and fellow companions about the distribution of Sawad agricultural land, it is possible to suggest that 'Umar used the approach of maqasid in making his decision. 'Umar did not agree with the opinion of many of the companions who regarded the properties as ghanima and needed to be distributed according to the standard formula. Hence, 'Umar made the decision to not distribute the portions according to the one fifth rate after he made further analysis towards the case and concluded that the properties should not be owned by only certain level of people. It can therefore be assumed that 'Umar's action was meant to narrow the gap of economic level among people and to guarantee the preservation of food sources which can be obtained from the agricultural land for the future generations. Another possible explanation for this might be that 'Umar's confidence to literally differ with the decision of Prophet Muhammad shows his vast understanding about the concept of maqasid. Even though the Quran and hadith physically mention about the matter, but the understanding, interpretation and application of the texts has been updated to take into account the current situation and needs. If the debate is to be move forward, a better understanding of maqasid needs to be developed. This is an important issue for future research.

\section{References}

Adam, Y. (1347). Kitab al-Kharaj. Cairo: Matba‘a Qahira.

Al-Bukhari, M. (2003). Sahih al-Bukhari. Cairo: Maktabah al-Safa.

Al-Jammal, M. (1980). Mausu'at al-Iqtisad al-Islami. Cairo: Dar al-Kitab al-Misr.

Al-Kindi, A. (1984). Al-Musannaf. Masqat: Wizara al-Turath al-Qauma wa al-Thaqafa.

Al-Mawardi, A. (2002). Kitab al-Ahkam al-Sultaniyya. Cairo: Dar al-Hadith.

Al-Qaradawi, Y. (2009). Figh al-Jihad: Dirasa Muqarana li Ahkamihi wa al-Falsafatihi fi Dau' al-Qur'an wa al-Sunna. Cairo: Maktaba Wahba.

Al-Qasim, A. (1989). Kitab al-Amwal. Beirut: Dar al-Syuruq.

Al-Rahibi, M. (1973). Fiqh al-Muluk wa Miftah al-Ritaj al-Mursad 'ala Khizana Kitab al-Kharaj. Baghdad: Matba'a al-Irsyad.

Al-Sarakhsi, S. (1906). Kitab al-Mabsut. Cairo: Matba'a al-Sa'ada.

Al-Shaybani, M. (1997). Sharh Kitab al-Siyar al-Kabir. Beirut: Dar al-Kutub al-'Ilmiyya.

Al-Ṭabari, M. (1961). Tarikh al-Tabari. Cairo: Dar al-Ma'arif.

Al-Zarqa, A. (1989). Sharah al-Qawa'id al-Fiqhiyya. Dimashq: Dar al-Qalam.

Azad, A. (1982). Rasul Rahmat. Delhi: I'tiqad Publishing House. 
Badara, M. \& Nagatab, M. (2017). Modern Extremist Groups and the Division of the World: A Critique from an Islamic Perspective, Arab Law Quarterly, 31(4), 305-335. https://doi.org/10.1163/15730255-12314024

Bouzenita, A. (2007). The Siyar-An Islamic Law of Nations?. Asian Journal of Social Science, 35(1), 19-46. https://doi.org/10.1163/156853107X170150

Brockelmann, C. (1952). History of the Islamic Peoples. London: Lund Humphries.

Firdaus, M. (1999). The Effect of Social Changes Towards the Laws of Islam. PhD Thesis, Academy of Islamic Studies, University of Malaya.

Guillaume, A. (1998). The life of Muhammad: a translation of Ishaq's Sirat rasul Allah. Oxford: Oxford University Press.

Hamidullah, M. (1941). The Muslim Conduct of State. Hyderabad: The Manorma Press, 1941.

Haron, Z. \& Hussin, N. (2013). A Study of the Salafi Jihadist Doctrine and the Interpretation of Jihad by Al-Jama'ah Al-Islamiyah, Kemanusiaan, 20(2), 15-37.

Ibn Taymiyya, A. (1991). al-Siyasa al-Shar'iyya fi Islah al-Ra'i wa al-Ra'iyya. Maghrib: Dar alAfaq al-Jadida.

Ishak, M. (2000). Umar ibn al-Khattab: Implementation of Islam Law. Skudai: UTM Publisher. Islahi, A. (1988). Economic Concepts of Ibn Taymiyyah. Leicester: The Islamic Foundation.

Kelsay, J. (2003). Al-Shaybani and the Islamic Law of War. Journal of Military Ethics, 2(1), 6375. https://doi.org/10.1080/15027570310000027

Khadduri, M. (1955). War and Peace in the Law of Islam. Baltimore: The Johns Hopkins Press. Khalilieh, S. (1998). Islamic Maritime Law: An Introduction. Leiden: E.J Brill.

Latif, M. (2014). Discourse of Communication in the al-Qur'an: An Analysis Towards a Twoway Dialogue. PhD Thesis, Academy of Islamic Studies, University of Malaya.

Lings, M. (1983). Muhammad: His Life Based on the Earliest Sources. Cambridge: The Islamic Text Society.

Majid, M. (2012). Maqasid al-Shariah: an Introduction. In Maqasid al-Syariah (pp. 35-43). Gombak: IIUM Press.

Mitrasing, I. (2014). Negotiating a New Order in the Straits of Malacca (1500-1700), Kemanusiaan, 21(2), 55-77.

Muslim, A. (2010). Sahih Muslim. Cairo: Dar al-Hadith.

Omer, S. (2014). From Mosques to Khanqahs: The Origin and Rise of Sufi Institutions. Kemanusiaan, 21(1), 1-19.

Rushd, M. (1984). al-Bayan wa al-Tahsil wa al-Sharh wa al-Taujih wa al-Ta'lib fi Masa'il alMustakhraja. Beirut: Dar al-Gharb al-Islama.

Rushd, M. (1988). Bidaya al-Mujtahid wa Nihaya al-Muqtasid. Beirut: Dar al-Kutub al-'Ilmiyya. Sa'd, M. (1957). Kitab al-Tabaqat al-Kubra. Beirut: Dar al-Sadir.

Sharif, M. F. (2006). Baghy in Islamic Law and the Thinking of Ibn Taymiyya, Arab Law Quarterly, 20(3), 289-305.

Sharif, M. F. (2011). Ibn Taymiyyah on Jihad and Baghy. Pulau Pinang: Penerbit Universiti Sains Malaysia.

Sharif, M. F. (2017). Perayaan Maulid Menurut Ibnu Taymiyyah dalam Iqtid̄ā' (The Maulid Festival According to Ibnu Taymiyyah in Iqtị̣a $\left.\bar{a}^{\prime}\right)$, Kemanusiaan, 24(1), 51-80. https://doi.org/10.21315/kajh2017.24.1.3

Siddiqi, M. (1989). Role of Booty in the Economy during the Prophet's Time, JKAU: Islamic Econ, 1(2), 83-115.

Yusuf, A. (1970). Kitab al-Kharaj. Beirut: Dar al-Ma'rifa.

Yusuf, A. (n.d.). Al-Radd 'ala Siyar al-Auza'i. Cairo: Maktabat Dar al-Hidaya. 
INTERNATIONAL JOURNAL OF ACADEMIC RESEARCH IN BUSINESS AND SOCIAL SCIENCES Vol. 11, No. 10, 2021, E-ISSN: 2222-6990 @ 2021 HRMARS

Zahir, A. (1980). Mohammad. Delhi: Radjani Press. 